$<$ 原 著 $>$

門脈圧亢進症に特ける肝静脈造影衫よび逆行性門脈造影の

診断的意義に関する研究

\title{
福永 正氣*
}

要 旨：肝内性門脈圧六進症に括ける肝静脈造影括よび逆行性門脈造影の診断的意義について 検討した. 変数選択型判別分析による正診率は, 肝硬変症(以下 LC とする) 159 例中151例95\%, 乙'型肝硬変症 7 例中 6 例 $86 \%$, 原発性胆汁性肝硬変症 6 例中 5 例 $83 \%$, 特発性門脈圧元進症は 21例中 12 例 $57 \%$ であった，誤診例を詳細に分析すると本法はきわめて忠実に肝病変を反映する ため, 肝生検, 肝表面像を含め総合評価することにより，より正確な門脈圧元進症の形態診断 に到達しうると考えられた。 LCの造影所見を成因別に検討するとアルュール性 LCは非アル コール性 LC に此較して壁不整, 屈曲・蛇行の著明な I 型が有意に少なく，これはアルコール性 LCの再生結節径が他群に比較して有意に小さなことを反映した造影上の相違と推測され, 造 影所見の検討が成因を考える上で有力な一手段となりらることが示唆された。

索引用語： 肝静脈造影逆行性門脈造影 門脈圧方進症原発性胆汁性肝硬変症 フルコール性肝硬変症

\section{緒言}

阴脈圧穴進症（以下門忘症とする）の原疾患は多岐 にわたる、これら疾患の肝内血管系に与える変化に関 する研究は主に剖検肝で行われ，多くの業績1,2)があ る. 肝静脈造影法を初めて臨床応用し，肝静脈系の変 化に検討を加えたのは1953年 Tori ${ }^{3)}$ ，上田らである.逆 行性門脈造影法は1961年小倉ら ${ }^{43}$ にり初めてその臨 床的意義について報告された，その後，門六症の疾患 別の造影所見と病理所見の比較 ${ }^{46)}$, 鑑別診断能の検 討 ${ }^{5-8)}$ ，肝機能との相関 ${ }^{6,8,9)}$ な゙，多くの報告がみられ る. 鑑別診断能は典型的症例では招扣むね良好である が，境界域にある症例では必ずしも容易でなく，判読 医の主観的要素が判定に組み込まれ易い，今回，われ われはこの主観的要素を可及的排除し，判定を単純化 した上で変数選択型判別分析を行った. 肝外性門元症 は各種造影法で診断が容易なため，本研究では肝内性 門充症である肝硬変症(以下 LC とする)，乙型肝硬変 症 (以下乙'-LC とする)，特発性門六症 (以下 IPH と する), 原発性胆汁性肝硬変症 (以下 PBC とする) の 4 疾患を対象とし，診断能を検討した，次に最も頻度 の高いLCの造影所見を成因, 再生結節径, 肝表面像か

* 順天堂大学第 2 外科学教室 〈受付日61年10月15日 $>$
ら比較し，肝静脈造影法が成因分類に果たす意義につ いて検討した。

\section{研究対象}

対象は昭和 54 年 9 月より59年12月までに当科に入院 加療した門元症患者464例のらち, 肝静脈造影および逆 行性門脈造影が施行し光た症例で，しかむ病理学的診 断の確定し之た LC 211例, 乙' '-LC 7 例, IPH 21例, $\mathrm{PBC} 6$ 例, 計245例である. $\mathrm{PBC}$ の 1 例は病理学的検 索はなされていないが，「難治性の肝炎調查研究班」の 「自己免度性肝炎分科会」の診断基準を満たすため対象 に含めた。

\section{研究方法}

\section{1. 肝静脈造影おょび逆行性門脈造影法}

肝静脈造影は昭和54年 9 月より56年 6 月までの症例 はCournand 8F カテーテルを右大腿静脈より Seldinger 法に準じて插入し，原則として右肝静脈主枝にカ テーテルを進め, 先端を wedge させた後に5 6cm 引 き抜いた位置で $60 \%$ Amidotrizoate $20 \mathrm{~m} l$ を自動注入 器で 3 秒間で注入し造影した. 逆行性門脈造影は再び カテーテルを wedge させ，造影剂約 $30 \sim 40 \mathrm{~m} l$ を用手 的に可及的速やかに注入し造影した，56年 7 月以後の 症例は8F バルンカテーテルを主枝の下大静脈流入部 になるべく近位で膨張させ肝静脈を遮断し，造影剂約 6 9m l を使用し肝静脈造影を行った．次いでカテー 
$88: 940$

肝

灀

テルを wedgeさせ，さらにバルンをわずかに膨張さ せ，造影剂約30～40m $l$ を使用し逆行性閅脈造影を 行った。

\section{2. 肝静脈造影および逆行性門脈造影所見の検討}

検討項目は13項目である，肝静脈造影所見は中一細 枝（2－6 分枝）の10項目である．壁不整，屈曲・蛇 行をそれぞれ認めない(一)，軽度に認める(十)，高 度に認める（H）とした。急狭化 (Abrupt tapering)， 狭小化 (Narrowing)，鈍角化，鋭角化，分枝減少，中 断，うねり・伸展の各所見をそれぞれ認めない(一)， 認めるもの (十) とした，肝静脈枝相互間吻合は認め ない(一), 中一細枝間で 1 2 本の吻合を認める(十), 数本以上の吻合を認め，しかも吻合枝への造影剂の棃 行が良好なるの（\#）とした。逆行性門脈造影は 3 項 目を検討した，X線学的肝縁凹凸像を認めない(一), 認めるもの（十）とした，類洞充満像は斑紋を認めな い(一)，小さな斑紋を認める(十)，大きな斑紋を認 めるすの（サ）とした．肝内門脈枝造影度はまったく 造影されない 0 度から門脈本幹付近まで造影される 5 度まで 6 段階で検討したが，今回は肝内門脈第 2 分岐 （後下行枝ではいわゆる P point）まで造影されない2 度までを(ー)，3 度以上を(十）とした。

\section{3. 肝硬变症の成因分類}

28巻 7 号 (1987)

フルコール性 LC (以下 $\mathrm{Al}$ 群とする) は文部省科学 研究費総合研究「アルコールと訮」研究班の診断基準 に相当する大酒家で, $\mathrm{HBsAg}(-)$, 輸血歴のない症例 とした。 B 型肝资ウイルス性 LC (以下 HB 群とする) はHBsAg (十)で领酒歴のない症例とした，大酒家で $\mathrm{HBsAg}(+)$ の症例は $\mathrm{Al}+\mathrm{HB}$ 群, 大酒家で輸血歴の ある症例は $\mathrm{Al}+\mathrm{BT}$ 群とした。これら以外の症例で輸 血歴のみ認める症例を $\mathrm{BT}$ 群, その他をC群とし, 計 6 群に分類した。

\section{4. 病理学的再生結節径の測定法}

外科的訮生検材料の訮切片の銀染色または Hematoxylin Eosin 染色で結節形成明瞭な症例で, 観 察しえた最大結節の短径を再生結節徍とした.

\section{5. 肉眼的肝表面像の分類法}

肝表面の観察は大多数の症例で経胸食道離断術(杉 浦法）経腹操作時に行った．肝表面結節径 $2 \sim 3 \mathrm{~mm}$ 以 下を橴細顆粒状, 約 $5 \mathrm{~mm}$ 以上を粗大顆粒状とし, 結節 形成不明暸な症例は除外した。

\section{研究結果}

\section{1. 診断能の検討}

（1）疾患別の各造影所見出現頻度の比較 (Table 1) 対象はすべての造影所見検討可能な LC 159例，乙' LC 7 例, IPH 21例, PBC 6 例の計193例である. LC

Table 1 Frequency of venographic findings in the cases with various liver diseases.

\begin{tabular}{l|c|c|c|c} 
& $\begin{array}{c}\text { LC(\%) } \\
\mathrm{n}=159\end{array}$ & $\begin{array}{c}\mathrm{B}^{\prime} \cdot \mathrm{LC}(\%) \\
\mathrm{n}=7\end{array}$ & $\begin{array}{c}\text { IPH(\%) } \\
\mathrm{n}=21\end{array}$ & $\begin{array}{c}\text { PBC(\%) } \\
\mathrm{n}=6\end{array}$ \\
\hline Wall irregularity & $155 / 159(97)$ & $5 / 7(71)$ & $6 / 21(29)$ & $1 / 6(17)$ \\
\hline Bends and winding & $152 / 159(96)$ & $2 / 7(29)$ & $3 / 21(14)$ & $2 / 6(33)$ \\
\hline Abrupt tapering & $148 / 159(93)$ & $2 / 7(29)$ & $15 / 21(71)$ & $5 / 6(83)$ \\
\hline Narrowing & $50 / 159(31)$ & $2 / 7(29)$ & $1 / 21(5)$ & $0 / 6(0)$ \\
\hline Acute angle arbolization & $150 / 159(94)$ & $2 / 7(29)$ & $3 / 21(14)$ & $1 / 6(17)$ \\
\hline Wide angle arbolization & $3 / 159(2)$ & $1 / 7(14)$ & $12 / 21(57)$ & $4 / 6(67)$ \\
\hline Few branches & $71 / 159(45)$ & $1 / 7(14)$ & $8 / 21(38)$ & $2 / 6(33)$ \\
\hline Occulusion & $103 / 159(65)$ & $2 / 7(29)$ & $1 / 21(5)$ & $1 / 6(17)$ \\
\hline Tortuosity, extensive & $0 / 159(0)$ & $0 / 7(0)$ & $15 / 21(71)$ & $5 / 6(83)$ \\
winding & $4 / 159(3)$ & $1 / 7(14)$ & $14 / 21(67)$ & $2 / 6(33)$ \\
\hline Vein to vein shunts(+1) & $137 / 159(86)$ & $2 / 7(29)$ & $3 / 21(14)$ & $1 / 6(17)$ \\
\hline Uneven liver margin & $152 / 159(96)$ & $4 / 7(57)$ & $6 / 21(29)$ & $1 / 6(17)$ \\
\hline Sinusoidal filling spotted & $144 / 159(91)$ & $3 / 7(43)$ & $4 / 21(19)$ & $3 / 6(50)$ \\
\hline PV grade III & & \multicolumn{3}{|c|}{ PV: Opacification of portal branches }
\end{tabular}


は壁不整（+）以上 $97 \%$ ，屈曲·蛇行（+）以上 $96 \%$, 急狭化 $93 \%$ ，鈍角化 $94 \%$ ，肝縁の凹凸像 $86 \%$ ，類洞充 満像が斑紋を示す例 $96 \%$, 肝内門脈枝造影度 3 度以上

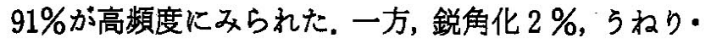
伸展 $0 \%$, 肝静脈枝相互間吻合 (H) $3 \%$ と出現率が 低かった，乙'-LCは壁不整71\%，類洞充満像が斑紋を 示す例 $57 \%$ 以外は各造影所見の出現率は低かった。 IPH は鋭角化 $57 \% ， \zeta 2 り ・$ 伸展 $71 \%$ ，肝静脈枝相互 間吻合(サ)側67\%と高率に認められたが, 壁不整 $29 \%$, 屈曲・蛇行 $14 \%$, 中断 $5 \%$, 肝縁の凹凸像 $14 \%$, 肝内 門脈枝造影度 3 度以上 $19 \%$ 之低率であった. PBCは各 造影所見ともIPH とほぼ同様な出現率を示したが, 肝 静脈枝相互間吻合の発達はやや不良, 肝内門脈枝造影 度はやや良好な傾向を示した。

（2）变数選択型判別分析による診断能の検討

判別分析は BMDP P7Mを使用した。判別項目（造 影所見) は前記13項目である. 4 疾患の判別は 3 つの 判別スコアよりなり, $\mathrm{fi}=\mathrm{ai}_{0}+\mathrm{ai}_{1} \mathrm{X}_{1}+\mathrm{ai}_{2} \mathrm{X}_{2}+\cdots+\mathrm{ai}_{\mathrm{n}}$ $\mathrm{X}_{\mathrm{n}}$ の判別式で示される、a は係数，Xは判別項目であ る.Xは取り込み順に $\mathrm{X}_{1}$ うねり・伸展, $\mathrm{X}_{2}$ 類洞充満像, $\mathrm{X}_{3}$ 屈曲・蛇行, $\mathrm{X}_{4}$ 肝静脈枝相互間吻合, $\mathrm{X}_{5}$ 肝内門脈枝 造影度， $\mathrm{X}_{6}$ 鈍角化， $\mathrm{X}_{7}$ 急狭化， $\mathrm{X}_{8}$ 壁不整， $\mathrm{X}_{9}$ 㹟小化の 9 項目が採用された。判別式は次式の如く導き出され た.

$$
\begin{aligned}
\mathrm{f}_{1}= & -2.65157-1.89759 \mathrm{X}_{1}+0.82260 \mathrm{X}_{2}+ \\
& 0.09425 \mathrm{X}_{3}-0.52848 \mathrm{X}_{4}+0.37100 \mathrm{X}_{5}+ \\
& 0.33259 \mathrm{X}_{6}+0.06732 \mathrm{X}_{7}+0.03310 \mathrm{X}_{8}- \\
& 0.11051 \mathrm{X}_{9} \\
\mathrm{f}_{2}= & 3.52119-0.82531 \mathrm{X}_{1}+0.14568 \mathrm{X}_{2}-0.54185 \\
& \mathrm{X}_{3}+0.14622 \mathrm{X}_{4}-0.25991 \mathrm{X}_{5}-0.22499 \mathrm{X}_{6}- \\
& 0.38049 \mathrm{X}_{7}+0.30635 \mathrm{X}_{8}+0.08897 \mathrm{X}_{9}
\end{aligned}
$$

$$
\begin{aligned}
f_{3}= & -2.50861-0.00947 \mathrm{X}_{1}+0.19452 \mathrm{X}_{2}- \\
& 0.17152 \mathrm{X}_{3}+0.89855 \mathrm{X}_{4}-0.15259 \mathrm{X}_{5}+ \\
& 0.050215 \mathrm{X}_{6}-0.03171 \mathrm{X}_{7}+0.29398 \mathrm{X}_{8}+ \\
& 0.00169 \mathrm{X}_{9}
\end{aligned}
$$

判別分析による猃断能の成績を Table 2に示す. LC は159例中151例正診率95\%で，7例が乙'-LC と，1例 が IPH と誤診した. 乙'-LCは 7 例中 6 例, 正診率 $86 \%$ で，1例が LC と誤診した. IPH は21例中12例，正診 率57\%であった。誤診は 9 例で， 5 例は PBC，3 例は 乙'-LC, 1 例は LC と誤診した. PBCは 6 例中 5 例, 正 診率83\%で，1 例は LC と誤診した。一方, 判別の対象 を乙'-LCを含めた LC と IPH，PBCを含めた非 LC の 2 群に限定し同様の判別分析を行 5 LC 166例中 165例, 正診率 $99 \%$, 非 LC 27例中 24例, 正診率89\%で, 全体で98\%の正診率であった。

(3) 正診例の検討

各疾患の判別スコフの平均からの距離の指標に Mahalanobis $\mathrm{D}^{2}$ (一般平方距離) がある。各疾患で本 值が 0 に近い程，その疾患の典型的造影所見を有して いる. Fig. 1は LC の症例である. 肝静脈枝は壁不整, 屈曲・蛇行, 鈍角化, 分枝減少, 中断を認め, 肝静脈 枝相互間吻合はわずかにみられる. Fig. 2は乙'-LCで ある. LCに比較し壁不整，屈曲・蛇行は軽度で，鋭角 化，らねり・伸展は認めない，Fig. 3はIPHである. 鋭角化， 5 ねり・伸展をみ，細い肝静脈枝相互間吻合 を多数認める. Fig. 4は PBCである. 軽度に鋭角化， らねり・伸展を認める. 肝静脈枝相互間吻合の発達は 軽度である。

（4）䜋診例の検討 (Table 3)

LCを乙'-LC と誤診した 7 例をみると, Child ${ }^{10)}$ A, B 群症例が 6 例を占め, Child C 群は 1 例のみであっ

Table 2 Correlation of results by stepwise discriminant analysis with histological diagnosis of liver diseases.

\begin{tabular}{l|c|c|c|c|cc}
\hline \multirow{2}{*}{$\begin{array}{c}\text { Diagnosis by } \\
\text { liver } \\
\text { histology }\end{array}$} & \multicolumn{4}{c}{ Diagnosis by stepwise discriminant analysis } \\
\cline { 2 - 7 } & LC & $\mathrm{B}^{\prime}$-LC & IPH & PBC & \multicolumn{2}{c}{ Accuracy rate } \\
\hline $\begin{array}{l}\text { LC } \\
\mathbf{n}=159\end{array}$ & 151 & 7 & 1 & 0 & $151 / 159$ & $95 \%$ \\
\hline $\begin{array}{l}\mathrm{B}^{\prime}-\mathrm{LC} \\
\mathrm{n}=7\end{array}$ & 1 & 6 & 0 & 0 & $6 / 7$ & $86 \%$ \\
\hline $\begin{array}{l}\mathrm{IPH} \\
\mathbf{n}=21\end{array}$ & 1 & 3 & 12 & 5 & $12 / 21$ & $57 \%$ \\
\hline $\begin{array}{l}\mathrm{PBC} \\
\mathrm{n}=6\end{array}$ & 1 & 0 & 0 & 5 & $5 / 6$ & $83 \%$ \\
\hline
\end{tabular}




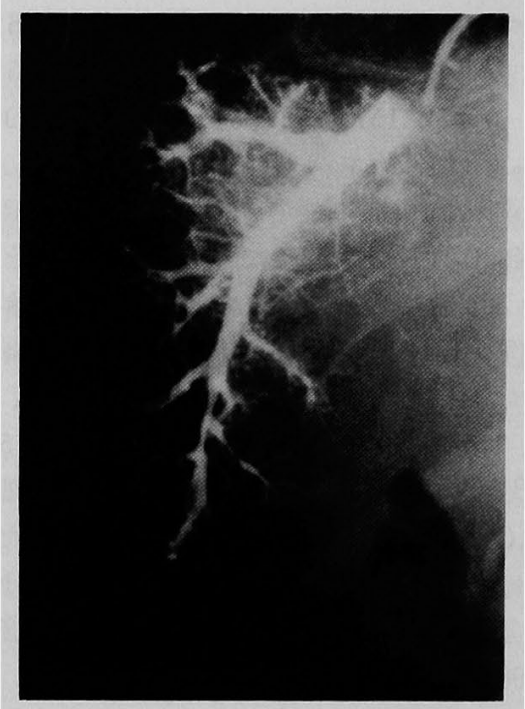

Fig. 1 Hepatic venogram in liver cirrhosis. The wall of branches is markedly irregular. Bends and winding, wide angle arbolization, few branches, occlusion are evident.

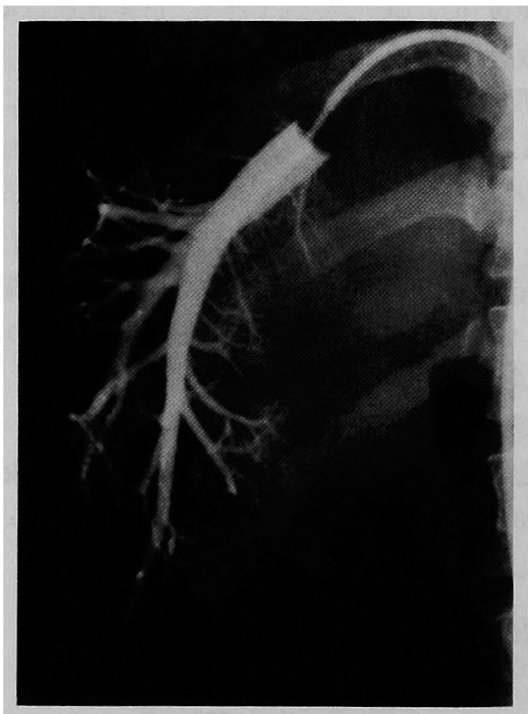

Fig. 2 Hepatic venogram in $\mathrm{B}^{\prime}$ type liver cirrhosis. There is no remarkable changes in middle to large branches. But in periphery, the wall of branches is slightly irregular.

た. 再生結節径をみると, $3 \mathrm{~mm}$ 以下が 6 例中 5 例を占 め, 肝表面像では微細顆粒状を示す例が 7 例中 6 例を 占めた。 LC を IPH と誤診した 1 例は外科的肝生検材 料では LC の診断であるが，48藏女性で肝機能障害は 軽く，巨脾を有し，肝表面は結節形成はなく，波打ち

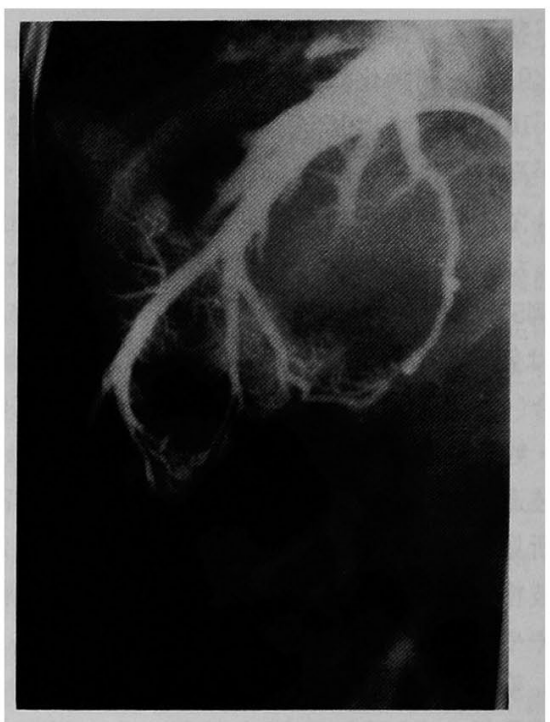

Fig. 3 Hepatic venogram in idiopathic portal hypertension. Acute angle arbolization, tortuosity and extensive winding are visible. Many vein to vein shunts are evident. There is no wall irregularity.

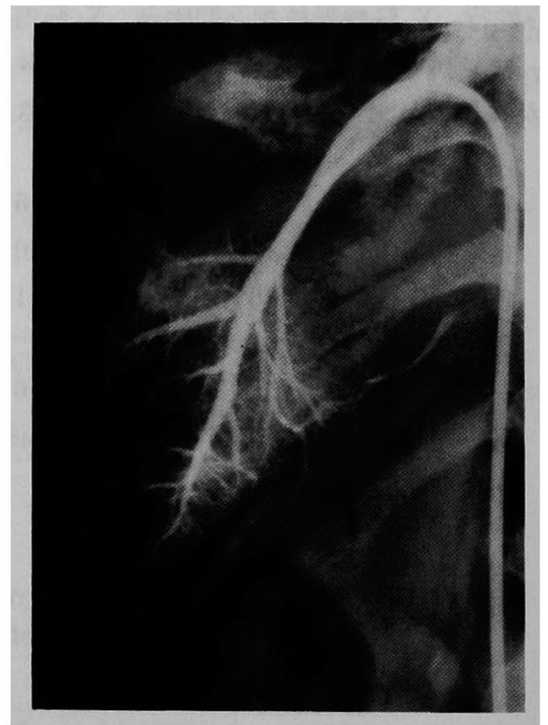

Fig. 4 Hepatic venogram in primary biliary cirrhosis. Acute angle arbolization, tortuosity and extensive winding are not so obvious, vein to vein shunts are slightly seen.

状所見を示した. IPH を乙'-LC と蕠診した 3 例は全例 らねり・伸展を認めなかった，IPHを PBC と誤診した 5 例はとすにうねり・伸展を認めるが，肝静脈枝相互 間吻合(サ)例は 5 例中 1 例のみであった. PBCを LC 
Table 37 cases of liver cirrhosis misdiagnosed as B' $^{\prime}$-type liver cirrhosis by stepwise discriminant analysis.

\begin{tabular}{c|c|c|c|c|l}
\hline Case & Age & Sex & $\begin{array}{c}\text { Child's } \\
\text { classification }\end{array}$ & $\begin{array}{c}\text { Size of regenerated } \\
\text { nodule(mm) }\end{array}$ & $\begin{array}{c}\text { Shape of } \\
\text { liver surface }\end{array}$ \\
\hline K.T. & 54 & Male & B & 2.6 & fine granular \\
\hline F.S. & 55 & Female & C & - & fine granular \\
\hline K.T. & 37 & Male & A & 2.0 & fine granular \\
\hline I.M. & 58 & Female & B & 2.6 & flat \\
\hline K.K. & 40 & Male & B & 2.0 & fine granular \\
\hline I.K. & 49 & Male & A & 2.6 & fine granular \\
\hline Y.K. & 75 & Female & A & 5.0 & fine granular \\
\hline
\end{tabular}

々誤診した 1 例は血清総ビリルビン $6.4 \mathrm{mg} / \mathrm{d} l$ の高度 黄㾝例であるが，病理末検索例であった。

\section{2. 肝硬变症の造影所見の検討}

（1）造影所見と成因の比較（Fig. 5)

造影所見13項目中，成因により有意差を認めたのは 壁不整 (H)，屈曲・蛇行 (H)，㹟小化，類洞充満像 が大きい斑紋を示す例の 4 項目であった，壁不整(サ) 例は $\mathrm{Al}$ 群60例中 9 例15\%, HB 群23例中 14 例 $61 \%$ で HB 群は有意に出現率が高かった $(\mathrm{p}<0.001)$ ．他群で はすべて Al 群との間に有意差を認めたが, HB 群とは 差を認めなかった，屈曲・蛇行 (十t) 例は $\mathrm{Al}$ 群60例中 7 例 $12 \%$, HB 群 23 例中 17 例 $74 \%$ で HB 群に有意に高 率であった $(\mathrm{p}<0.001)$. 他群ではすべて Al 群との間 で有意差を認めたが, HB 群とは差を認めなかった。狭

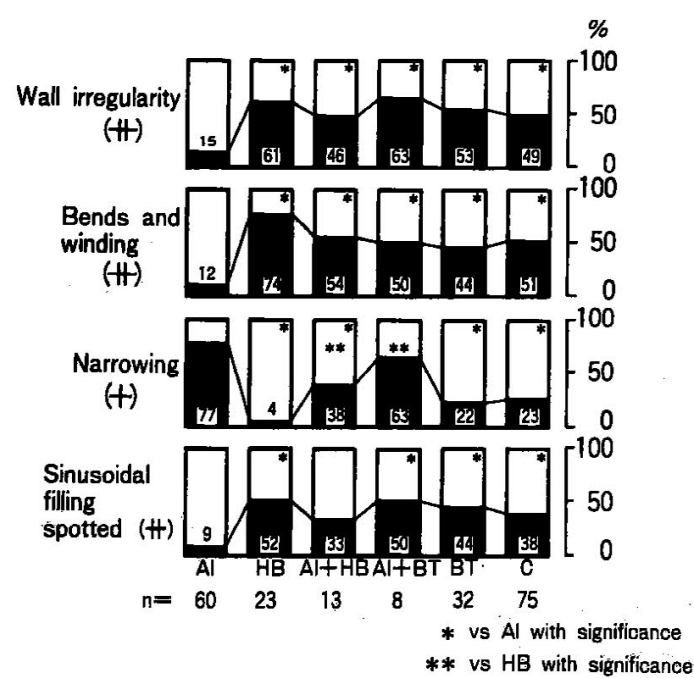

Fig. 5 Differences of venographic findings in various causes of liver cirrhosis (\%).
小化は $\mathrm{Al}$ 群60例中 46 例 $77 \% ， \mathrm{HB}$ 群23例中 1 例 $4 \%$ で, $\mathrm{Al}$ 群に有意に高率であった $(\mathrm{p}<0.001)$. 類洞充満 像が大きな斑紋を示す例は $\mathrm{Al}$ 群57例中 5 例 $9 \%, \mathrm{HB}$ 群21例中 11 例52\%であり，HB 群の斑紋が有意に大き かった ( $\mathrm{p}<0.001)$. 他群では $\mathrm{Al}+\mathrm{HB}$ 群を除き $\mathrm{Al}$ 群 より大きな斑紋を示したが，HB 群と差がなかった，以 上より肝静脈造影全体像を，I型：壁不整，屈曲・蛇 行が著明で狭小化は目立たない(Fig. 6). II 型：壁不 整，屈曲・蛇行は軽く，㹟小化が目立つ（Fig. 7). III 型：I，II 型の判別困難例として成因別に比較すると Fig. 8の如くなる. I 型の出現率を比較すると $\mathrm{Al}$ 群60

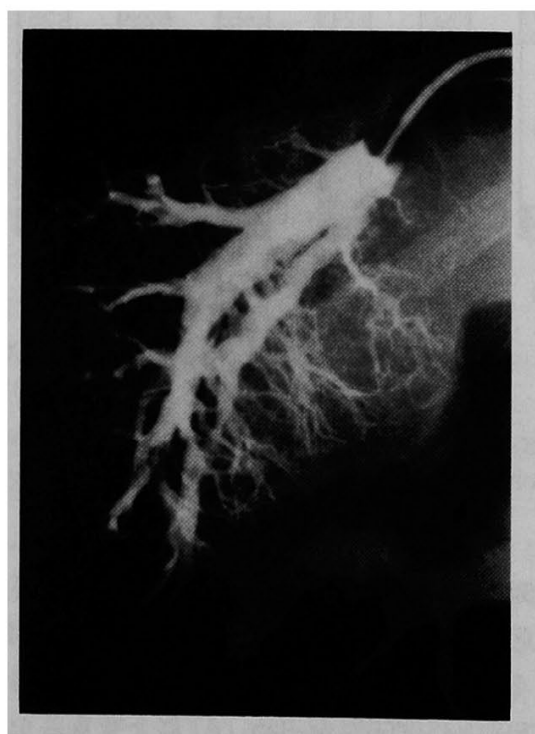

Fig. 6 Hepatic venogram in type I liver cirrhosis. Wall irregularity, bends and winding are dominant in middle to large branches. But narrowing is not so evident. 


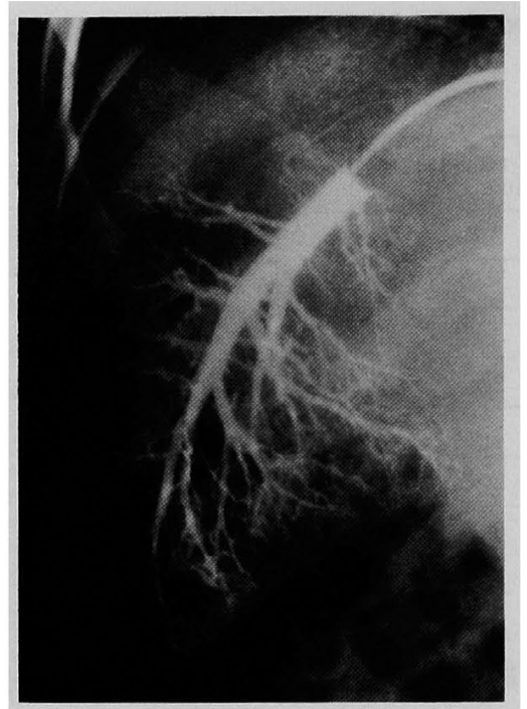

Fig. 7 Hepatic venogram in type II liver cirrhosis. The wall of braches is narrow in small to middle branches, but wall irregularity, bends and winding are not so evident in middle to large branches as compared with type I liver cirrhosis.

$\mathrm{n}=211$

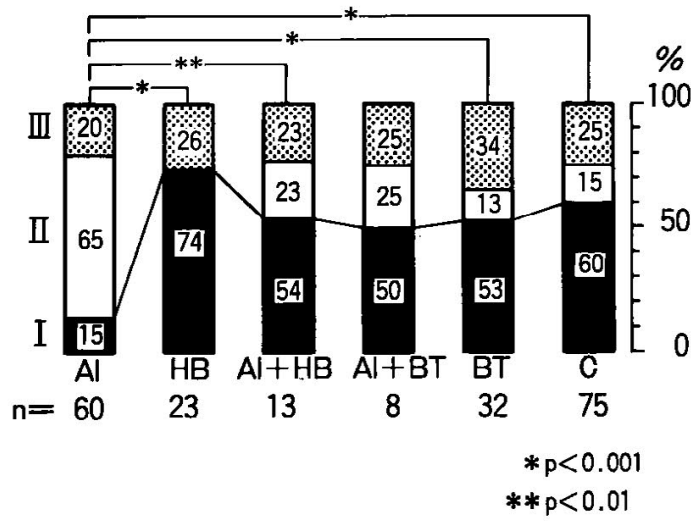

Fig. 8 Relationship between causes of liver cirrhosis and type of venographic findings.

例中 9 例 $15 \%, \mathrm{HB}$ 群23例中 17 例 $74 \%$ で HB 群の出現 率が有意に高かった $(p<0.001) . A 1+H B$ 群, BT 群, C 群は I 型がそれぞれ13例中 7 例 $54 \% ， 32$ 例中17例 $53 \% ， 75$ 例中 45 例 $60 \%$ を占め， $\mathrm{Al}$ 群と有意差を認めた $(\mathrm{Al}+\mathrm{HB}$ 群 $: \mathrm{p}<0.01, \mathrm{BT}$ 群, C群 $: \mathrm{p}<0.001)$ か;， HB 群との間には差を認めなかった。

（2）造影所見と再生結節径の比較（Fig. 9)

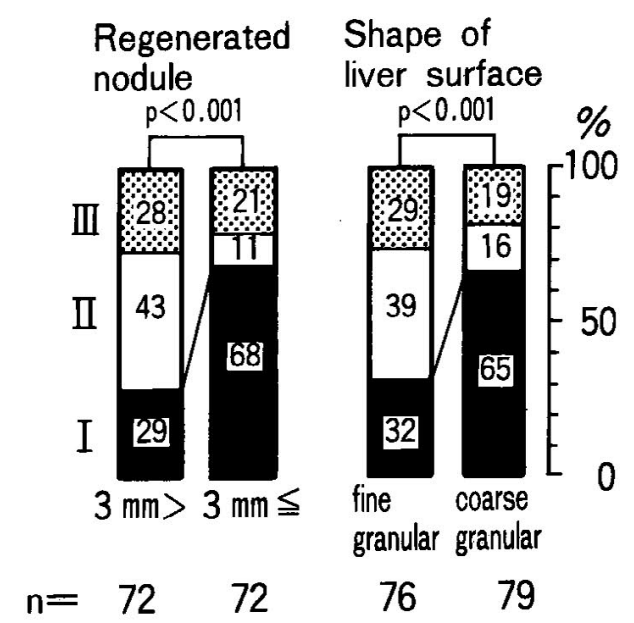

Fig. 9 Ralationship between type of venographic findings and size of regenerated nodule, shape of liver surface.

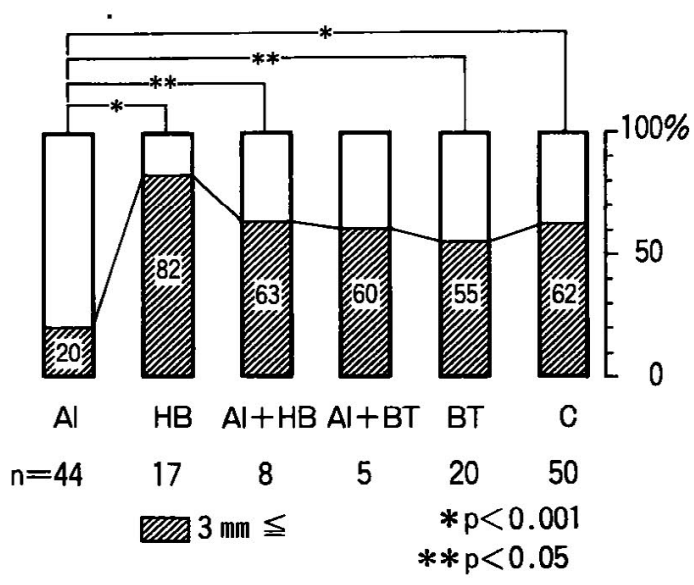

Fig. 10 Relationship between size of regenerated nodule and causes of liver cirrhosis.

病理学的に再生結節径を測定しえたのは144例であ る.全体像で I 型の出現率を比較すると $3.0 \mathrm{~mm}$ 以上72 例中 49 例 $68 \%$ に対 L, $3.0 \mathrm{~mm}$ 末満例は 72 例中 21 例 $29 \%$ で, 3.0mm 以上例に I 型の出現率が有意に高かった $(\mathrm{p}<0.001)$.

（3）造影所見と肝表面像の此較（Fig. 9）

肝表面像を検討しえた症例は155例である.全体像で I 型の出現率をみると粗大顆粒状79例中51例 $65 \%$ であ り，微細顆粒状は76例中24例32\%で，粗大顆粒状に I 型が有意に高率であった（p<0.001）.

（4）再生結節径と成因の比較（Fig. 10)

再生結節径 $3.0 \mathrm{~mm}$ 以上例の出現率を成因別に比較 


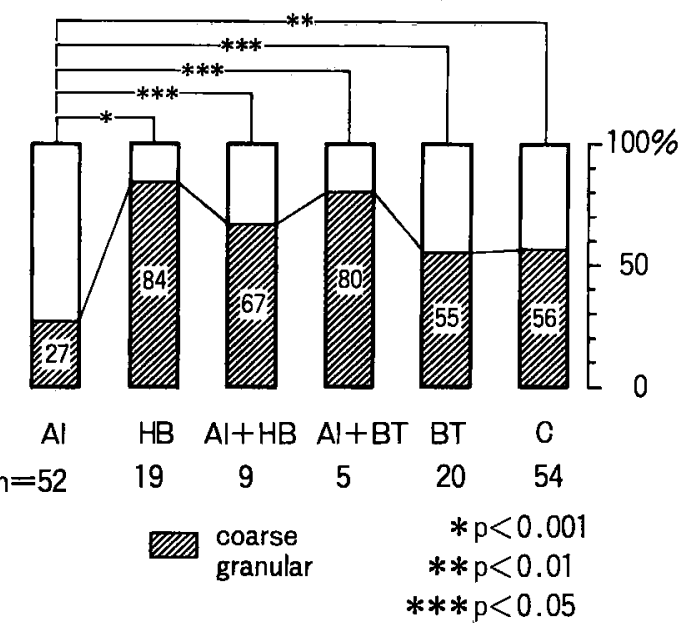

Fig. 11 Relationship between shape of liver surface and causes of liver cirrhosis.

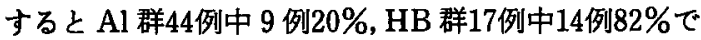
あり, $3.0 \mathrm{~mm}$ 以上例は $\mathrm{HB}$ 群に $\mathrm{Al}$ 群より有意に高率 であった ( $\mathrm{p}<0.001) . \mathrm{Al}+\mathrm{HB}$ 群， $\mathrm{BT}$ 群，C群はそ れぞれ 8 例中 5 例63\%，20例中11例55\%，50例中31例 62\%であり， $\mathrm{Al}$ 群との間に有意差を認めた（Al+HB 群, BT 群 : p <0.05, C 群 : p <0.001) が, HB 群と は差を認めなかった。 $\mathrm{Al}+\mathrm{BT}$ 群は 5 例中 3 例 $60 \%$ で あるが， Al 群， HB 群ともに有意差を認めなかった。

（5）肝表面像と成因の比較 (Fig. 11)

肝表面像が粗大顆粒状を示す例を成因別に比較する そ $\mathrm{Al}$ 群52例中14例 $27 \%, \mathrm{HB}$ 群19例中16例84\%であ り, $\mathrm{HB}$ 群は $\mathrm{Al}$ 群より粗大顆粒状を示す例が有意に高 率であった( $\mathrm{p}<0.001) . \mathrm{Al}+\mathrm{HB}$ 群， $\mathrm{Al}+\mathrm{BT}$ 群， $\mathrm{BT}$ 群，C群はそれぞれ 9 例中 6 例 $67 \%$ ，5 例中 4 例 $80 \%$ ， 20例中 11 例 $55 \%, 54$ 例中 30 例 $56 \%$ であり， $\mathrm{Al}$ 群との間 に有意差を認めた $(\mathrm{Al}+\mathrm{HB}$ 群, $\mathrm{Al}+\mathrm{BT}$ 群, $\mathrm{BT}$ 群 : $\mathrm{p}<0.05, \mathrm{C}$ 群： $\mathrm{p}<0.01)$ が，HB群とは有意差がな かった.

\section{1. 診断能について}

肝静脈の分岐は Elias ら ${ }^{11}$ が多彩な分岐形式を分類 しているが，中村 ${ }^{12)}$ は右肝静脈主枝は変異が少なく， 94\%が 1 本で, 解剖学的にす起始部は単純であるとし ている。われわれは右肝静脈主枝での造影を原則とし， 本検討でる92\%が同部での造影に成功した：肝静脈造 影は 3 次元構造を 2 次元に投影した造影であるが，同 一部位で比較しているため，部位による判読誤羑を軽 減しえたものと考えられた。疾患別にみた造影所見の
出現率をみると，LCは壁不整，屈曲・蛇行，急狭化， 鈍角化，類洞充満像が斑紋を示す例，肝内門脈枝造影 度 3 度以上例か $90 \%$ 以上の高率にみられ，鈍角化，5 ねり・伸展, 肝静脈枝相互間吻合が低率であった。 こ れは二川ら (13)の LCの造影所見の特徽および出現率の 報告にほぼ一致した。 乙'-LCは壁不整，類洞充満像の 斑紋を示す例がやや多くみられる以外，各造影所見の 出現率は低かった。吉本ら ${ }^{14} は 12$ 例の乙'-LCで検討 し, 肝静脈造影は LC の特徽を有し，逆行性門脈造影で はIPH に類似したと報告している．著者の検討では 乙'-LCは両造影とも正常例と LC の中間的所見であ り,吉本らとはやや異なる結果で,むしろ三宅が乙'-LC を乙型 LC の前硬变段階とした設定に一致する所見と 思われた，IPH は急狭化，鋭角化，5枋り・伸展が半 数以上にみられた. IPH 肝の特徵として相田 ${ }^{15}$ は病变 の程度と分布の不均一性, 福田ら ${ }^{16)}$ は肝静脈の变化を

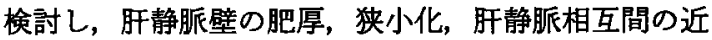
接化を認め,これにより造影所見の説明が可能である と報告している。 また肝静脈枝相互間吻合も IPH の肝 静脈造影上の大きな特徵である.この点に関しては小 倉ら4は肝静脈血流障害を是正するため，また福田 $ら^{16)}$ (肝実質の脱落の結果, 肝静脈枝相互間吻合が新 生されると推定している. 著者は IPH 以外に日本住血 吸虫症, 肝外門脈閉塞症, PBC, 肝部下大静脈閉塞症に おいても高度な肝静脈枝相互間吻合の発達を観察して いる．本吻合の意義，病理所見との対応についてはこ れら疾患を含めさらに倹討を要すると思われる。

PBC は肝静脈造影上ではIPHにきわめて近似して いた。肝内門脈枝造影度は IPH よりやや良好であった が，個々の症例でみると IPH の如くきわめて造影不良 例むある.これら所見はPBCの門六症の発症機序と して肝内門脈細枝の著明な狭小化による presinusoidal block であろらと組織計測面より検討した

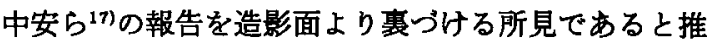
測された. PBC を含めた肝内性門光症の肝静脈造影お 上び逆行性門脈造影の診断能を判別分析を用いて検討 した報告は，いまだみられない. 判別成績をみると LC 95\%，乙'-LC 86\%，PBC 83\%と良好な正誩率であっ たが，IPH は57\%とやや低率であった，従来の診断能 に関する報告をみると，小倉 ${ }^{18)}$ は LC 51例，肝線維症 73例（乙'·LCを含む）の 2 疾患に限りこれを肝静脈造 影と逆行性門脈造影を用い比較し，ほぽ完全に鑑別可 能であったと報告している.

Bookstein ${ }^{5}$ は肝静脈造影の異常所見は LC の62\% 
にしかみられず，鑑別には閉塞肝静脈造影, 動脈造影, 閉塞肝静脈圧測定が必要であるとしている，市原ら7) は肝線維症と LCを比較し正診率88\%であったと報告 している. 一方，高安ら ${ }^{8)}$ は IPH を含む慢性肝疾患と LC 70例を比較して LC 73.2\%が高度变化群に含まれ るが，造影所見のみでは鑑別に充分ではないとしてい る. 著者は LC と非 LC の 2 群にのみ分類し判別分析 を行ならと正診辛 $98 \%$ \%゙，小倉らと同様，造影所見の みでほぼ完全に鑑別可能と思われた.しかし PBC，乙． LCを含め 4 疾患に細分し判别分析を行な5と IPH とPBCの造影所見が近似しているためIPHの正診 率が57\%にとどまり，臨床経過，抗ミトコンドリア抗 体など他のパラメーターを含め総合診断する必要があ ると思われた。

次に誤診例について検討した，LCを乙'-LC と誤診 した 7 例をみると，6 例はChild A, B 群の肝機能良好 群で, 再生結節径は小さく，肝表面像も微細顆粒状を

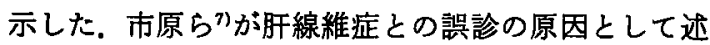
べている如く，われわれの症例も再生結節径が小さく 肝静脈壁へ与える影響が少ないため誤診したものと推 測された，LCをIPH と誤診したのは 1 例のみであっ た，本症例は病理学的にはLC と診断されたが，IPH はときに肝表面に部分的結節形成を認めることがあ $\eta^{15)}$, 他の IPH 特有な臨床像を考慮すると偶然再生結 節が採取された可能性が高い.IPHを乙'-LC 上誤診し たのは 3 例であった.これら個々の造影所見をみると， IPH，PBCにみられ，しか子取り込み順位が1位であ るらねり・伸展所見がなく，他の異常所見も軽度で, 比較的正常像に近かったことが判別に影響したものと 思われた. IPHを PBC と誤診したのは 5 例であった。 これらの症例は肝静脈枝相互間吻合の発達が不良で あった。しかし肝静脈造影および逆行性門脈造影は肝 全体の変化を肝血管系の変化を介して推測する検查法 であり，両疾患は前述の如く肝血管系に与える変化が 類似しており，このことが誤診の主因となったと推測 された。

PBCを LC と誤診したのは 1 例であるが, 造影上， 明らかな壁不整，屈曲・蛇行がみられた。本症例は高 度黄㾞を伴なう症候性 PBCで，病理末検索例である。 本例は再生結節形成の完成した Scheuer IV 期に相当 するため，造影上，LC と判定されたと推測された。

以上，判別分析による肝静脈造影扎よび逆行性門脈 造影の診断能について述べたが，誤診例を詳細に検討 を加えると本法が極めて忠実に肝病变を反映し，精度
の高い形態学的検查法であることが判明した，門䒕症 患者はしばしば出血傾向, 腹水, 原発性肝癌を合併し， 腹腔鏡，針生検は危険を伴なら。乙か子腹腔鏡による 肝表面像と針生検診断は必ずしも一致しない。針生検 はその切片が肝全体が的 $1 / 50,000$ 大ささにすぎず, 必ずしも肝全体の所見を反映するすのではないままた 針生検後の症例で著者は数例に A-P, A-V シャント形 成を経験している.とくに A-P シャントは門元症の増 悪因子となりらる．以上の理由でわれわれの門え症の 術前診断法として腹腔鏡，肝生検は行わず，肝静脈造 影, 逆行性門脈造影および選択的腹腔動脈造影を形態 学的診断法として採用している，肝生検と肝表面像の 観察は杉浦法経腹操作時に行い，これら検查法を併用 することにより，より確実な診断が期待できると思わ れた。

\section{2. 肝硬变症の造影所見の検討}

肝静脈造影全体像と成因の関係をみると Al 群はII 群が65\%を占め, I 型は15\%のみであるのに対し，HB 群, $\mathrm{Al}+\mathrm{HB}$ 群, BT 群, C群ではいずれる I 型が50\% 以上を占め，有意差を認めた。成因別に造影所見を検 討している報告は少ない。 Mann"2)，Bookstein²) Nutritional と Post-necrotic type を比較し両群間に 血管系の変化の差はないとしている. Smith ${ }^{91}$ は Nutritional と Post-necrotic type は明確に区別できない が，大結節であれば Post-necrotic typeを意味すると している. Cavaluzzi ${ }^{\text {() }} 3$ 例の Post-necrotic type 中 1 例で肝静脈の大きな壁不整をみ, Post-necrotic type が疑かれたが，両群を区別できないと報告している。 以上の如く造影所見のみでは成因の明確な判別は困難 であるとする報告が多いが，いずれの報告す Post-necrotic type の検討例が少なく不充分である，著者は造 影上て $\mathrm{Al}$ 群と $\mathrm{HB}$ 群, $\mathrm{Al}+\mathrm{HB}$ 群，BT 群，C群間に 㓍計学的に有意な差を認め, 従来の報告とは異なる結 果をえた。この成因による造影上の相違がどこに起因 するるのであるかを再生結節经, 肝表面像との関係よ り検討した. Popper ${ }^{1)}, \mathrm{Mann}^{2}$ (は剖検肝で肝静脈の壁 不整は再生結節による圧迫のためとしている，小合” は肝静脈造影所見と再生結節径を18例で検討し，径の 大きなるのは一般に肝静脈枝の変化が強く，造影所見 より再生結節径の推定が可能であると報告している。 著者は肝静脈造影と再生結節径を比較し，壁不整，屈 曲・蛇行の高度な I 型は再生結節径 $3 \mathrm{~mm}$ 以上例に有意 に多く，造影所見より結節径の推定が㴗ぼ可能であ。 た.さらに肝生検部位による結節径の大きさの差を排 
除する目的で造影所見と肝表面像を比較した。これた よると I 型は粗大顆粒状を示す例が有意に多く，肝表 面像は造影所見の分類に強く関与していると思われ た.

再生結節径と成因の関係をみると, $\mathrm{Al}$ 群の特徵は従 来, 小結節性とされている.小笠原 ${ }^{191}$ は微細顆粒状はつ ルコールが原因と考えられる症例のみにみられると述 ベている. 一方, Popperらはフルコール性 LCでも Post-necrotic LC の像をしばしば認めるとしている. 広瀬 ${ }^{201}$ はアルコールとHBゥイルスの両病因が肝に 作用すると壊死後性 LC の像を示すとしている，著者 の検討では $\mathrm{Al}$ 群の設定をかなり厳密に行ったことに もよると思われるが, $\mathrm{Al}$ 群は $\mathrm{HB}$ 群, $\mathrm{Al}+\mathrm{HB}$ 群, $\mathrm{BT}$ 群, C群より再生結節径が有意に小さく, 肝表面像も $\mathrm{Al}$ 群は他群に比較して有意に徽細顆粒状が多い結果 をえた。

以上より成因による造影所見の相違は造影所見が再 生結節径をよく反映し，再生結節径は成因により異な るためと推定された。つまり HB 群など非アルコール 群では再生結節径が大さなため壁不整, 屈曲・蛇行の 高度な I 型が多く，一方，Al 群は再生結節径が小さな ためI型が少なく，他群と異なる造影所見を示したと 思われた。このような事実は肝静脈造影所見が肝生検, 腹腔鏡などと同様，LC の成因診断上, 有力な一手段と なるすのと考えられた。

\section{結 語}

LC 204例，乙'-LC 7 例，IPH 21例，PBC 6 例の肝 静脈造影および逆行性門脈造影を検討し，以下の結論 を光た。

1. 変数選択型判別分析による正診率は LC 95\%, 乙'-LC 86\%，PBC 83\%でほほ满足すべき結果をえた が, IPHは57\%とやや低率であった。

2. LCを乙'-LC と㖞診した 7 例中 6 例恃再生結節 径が小さく，このため肝静脈壁に与える影響が少ない ことが誤診の原因と推測された.

3. IPH の正診率の低い主因は 5 例が PBC と誤診 したためで,これは両疾患の肝内血管系に与える変化 の類似性によるものと推測された。

4. 誤診例の検討より本法はきわめて忠実に肝病変 を反映し，有力な形態学的診断法と思われた。

5. LCの造影所見を成因別にみると Al 群は HB 群, $\mathrm{Al}+\mathrm{HB}$ 群, BT 群, C群に比較してI 型が有意に 少なく、これは $\mathrm{Al}$ 群の再生結節径が他群に比較して 有意に小さなことを反映した所見と推測され，肝静脈
造影は成因謬断の有力な一手段となるものと考えられ た.

本論文内容の一部は，第20回日本肝臟学会総会にて発表 した.

稿を終えるにあたり御指導，御校閲を賜った恩師杉浦光 雄教授深甚なる謝意を表します。また御協力, 御䩒撻下さ いました八木義弘教授，二川俊二助教授，深沢正樹講師なら びに教室員各位に感謝いたします。

\section{文 献}

1) Popper H, Elias H, Petty DE: Vascular pattern of the cirrhotic liver. Am J Clin Path 22 : 717-729, 1952

2) Mann JD, Wakim KG, Baggenstoss $A H$ : Alterations in the vasculature of the diseased liver. Gastroenterology $25: 540-546,1953$

3) Tori G: Hepatic venography in man. Acta Radiol 39: 89-97, 1953

4）小合正久：門脈圧方進症における肝静脈枝及び肝 内阴脈枝の变化に関する研究. 臨床消化器病学 $9: 867-890,1961$

5) Bookstein JJ, Appelman HD, Walter JF, et al : Histological-venographic correlates in portal hypertension. Radiology 116 : 565-573, 1975

6) Cavaluzzi JA, Sheff $R$, Harrington DP, et al : Hepatic venography and wedge hepatic vein pressure measurements in diffuse liver disease. Am J Roentgenol 129 : 441-446, 1977

7）市原荘六，深沢正樹，杉浦光雄，他：肝静脈撮影抽 よび逆行性門脈撮影の診断的意義. 脈管学 17 : 139-144, 1977

8）高安蜸一, 武者広隆, 奥田邦雄, 他：肝静脈カテー テル法を用いた肝診断とその診断限界一特に䀒静 脈造影所見に上る肝硬变症と他疾患との鑑別につ いて一. 日消会誌 $75: 1623-1632,1978$

9) Smith GW, Westgaard T, Djorn-Hansen R: Hepatic venous angiography in the evaluation of cirrhosis of the liver. Ann Surg 173: 469 $-480,1971$

10) Child CG III : The liver and portal hypertension. WB Saunders, Philadelphia, 1964

11) Elias H, Petty DE: Gross anatomy of the blood vessels and ducts within the human liver. Am J Anat 90 : 59-111, 1952

12）中村 達 : 肝静脈および下大静脈の外科的解剖に 基づいた肝切除術の検討。日外会誌 83：384 
$-395,1982$

13) Futagawa $S$, Sugiura $M$, Okuda $K$, et al : Hepatic venography in non cirrhotic idiopathic portal hypertension. Radiology 141 : 303-309, 1981

14）吉本賢隆, 渡辺五郎, 深沢正樹, 他: 乙'型肝硬変 症の肝静脈造影所見の検討. 厚生省特定疾患門脈 王六進症調查研究班, 昭和54年度報告書, 1980 , p218-221

15）相田尚文：特発性門脈圧六進症肝の病理学的なら び組織計測的研究. 肝澸 $22: 656-675,1981$

16）福田一典, 鹿毛政義, 荒川正博, 他：特発性門脈圧 充進症に乱ける肝内肝静脈の病理学的変化につい
て. 肝藏 $23: 1015-1023,1982$

17）中安安二, 太田五六：原発性胆汁性肝硬変と門脈 王六進；その成因に関する組織計測学的研究と他 の慢性疾患との対比。肝䑏 $20: 388-395,1979$

18）小倉正久, 杉浦光雄, 市原荘六, 他：肝静脈撮影法 からみた肝疾患一とくに肝硬変症と肝線維症につ いて一. 肝葴 $9: 191,1968$

19）小笠原久隆, 堀口正晴, 永山和男, 他：肝硬変に和 ける肝内血管变化について. 肝蔵 24：1252 $-1261,1983$

20）広瀬鎮郎，太田五六，吉沢浩司：肝内 HB 抗原に上 るアルコール多领者肝硬変の形態学的修飾につい て. 肝䁍 $18: 625-633,1977$

\section{Diagnostic significance of hepatic venography and retrograde portography in portal hypertension}

\section{Masaki FuKunAGA*}

In this series, we studied about diagnostic significance of hepatic venography and retrograde portography in portal hypertension by using stepwise discriminant analysis. The accuracy rate of the discrimination was $95 \%$ in liver cirrhosis (LC), $86 \%$ in B' type LC, $83 \%$ in primary biliary cirrhosis (PBC) and $57 \%$ in idiopathic portal hypertension (IPH). The difficulty in differential diagnosis of IPH from $\mathrm{PBC}$ was due to similarity of hepatic vascular changes in both diseases. Next we studied about the relationship between venographic findings and the causes of LC. The size of regenerated nodule in alcoholic LC was significantly smaller than the others, so venographic findings were different from others. It was concluded that hepatic venography was useful examination for differential diagnosis in portal hypertension, and was effective for considering about the causes of LC.

* The Second Department of Surgery, Juntendo University, School of Medicine (Tokyo) 